\title{
対話解析のためのゼロ代名詞照応解析付き述語項構造解析
}

\author{
今村 賢治 ${ }^{\dagger}, \dagger \cdot$ 東中竜一郎 ${ }^{\dagger}$ 泉 朋子†
}

本稿では, 日本語を対象とした対話用述語項構造解析を提案する。従来, 述語項構 造解析は, 主に新聞記事を対象に研究されてきた。新聞と対話ではさまざまな違い が存在するが, 本稿ではこれを包括的に扱うため, 対話用述語項構造解析器の構築 を, 新聞から対話への一種のドメイン適応とみなす。具体的には, 対話では省略や 代名詞化が新聞記事に比べて頻繁に現れるため, ゼロ代名詞照応機能付きの述語項 構造解析をべースとし，これを対話に適応させる，パラメー夕適応と，訓練コーパ スがカバーしきれない語彙知識を大規模平文コーパスから自動獲得することにより， 新聞記事用のものに比べ, 対話に対して高精度な述語項構造解析を実現した.

キーワード：述語項構造解析, ゼロ代名詞照応, 対話, ドメイン適応, 係り受け言語モデル

\section{Predicate-Argument Structure Analysis and Zero-Anaphora Resolution for Dialogue Analysis}

\author{
Kenji Imamura $^{\dagger} \dagger^{\dagger}$, Ryuichiro Higashinaka ${ }^{\dagger}$ and Tomoko Izumi ${ }^{\dagger}$
}

This paper presents a predicate-argument structure (PAS) analysis for dialogue systems in Japanese. Conventional PAS analyses have been applied to newspaper articles; however, there are differences between newspapers and dialogues. Therefore, to comprehensively deal with these differences, we constructed a PAS analyzer for dialogues as a type of domain adaptation from newspapers. Because pronominalization and ellipses frequently appear in dialogues, we utilized a strategy that simultaneously resolves zero-anaphora and adapts our PAS analyzer to dialogues. By incorporating parameter adaptation and automatically acquiring knowledge from large text corpora, we performed a PAS analysis that is specific to dialogues. Our PAS analyzer has a higher accuracy compared with the analyzer for newspaper articles.

Key Words: Predicate-Argument Structure Analysis, Zero-anaphora Resolution, Dialogue, Domain Adaptation, Dependency Language Models

\section{1 はじめに}

述語項構造解析 (predicate-argument structure analysis) は，文から述語とその格要素（述語 項構造）を抽出する解析タスクである。述語項構造は，「誰が何をどうした」を表現している

†日本電信電話株式会社, NTT メディアインテリジェンス研究所, NTT Media Intelligence Laboratories, NTT Corporation

†† 現在, 独立行政法人情報通信研究機構, Presently with National Institute of Information and Communications Technology 
ため, この解析は, 文の意味解析に位置付けられる重要技術の一つとなっている. 従来の述語 項構造解析技術は，コーパスが新聞記事であるなどの理由で，書き言葉で多く研究されてきた (Carreras and Màrquez 2004, 2005; 松林, 飯田, 笹野, 横野, 松吉, 藤田, 宮尾, 乾 2014) .

一方，近年のスマートフォンの普及に伴い，Apple社の Siri, NTTドコモ社のしゃべってコ ンシェルなど，音声による人とコンピュータの対話システムが，身近に使われ始めている．人． コンピュータの対話システムを構築するためには, 人間の発話を理解し, システム発話ととも に管理する必要があるが, 述語項構造は, 対話理解・管理に対しても有効なデータ形式である と考えられる。しかし，新聞記事と対話では，発話人数，口語の利用，文脈など，さまざまな 違いがあるため, 既存の新聞記事をベースとした述語項構造解析を対話の解析に利用した際の 問題は不明である。たとえば，以下の対話例を考える。

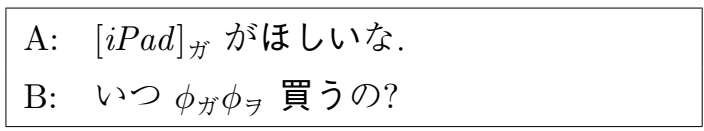

この例では, 最初の発話から, 述語が「ほしい」, そのガ格が「iPad」である述語項構造が抽出 される，2番目の発話では，述語が「買う」であることはわかるが，ガ格， ヨ格が省略されてい るため, 述語項構造を得るためには，方格が発話者 $\mathrm{A}$ ， ヨ格が「iPad」であることも併せて解 析する必要がある。このように，対話では省略がごく自然に出現する（これをゼロ代名詞と呼 ぶ）ため, 日本語の対話の述語項構造解析には, ゼロ代名詞照応解析処理も必要となる.

本稿では, 人とコンピュータの対話システム実現のため, 従来に比べ対話を高精度に解析す る述語項構造解析を提案する。本稿で対象とする夕スクは，以下の 2 点をともに解決するもの である。

（1）日本語で必須格と言われているガ格, ヨ格, 二格に対して, 述語能動形の項を決定する.

（2）ゼロ代名詞照応解析を行い, 文や発話内では項が省略されている場合でも, 先行した文 脈から項を決定する。

本稿の提案骨子は, 対話のための述語項構造解析器の構築を, 新聞から対話へのドメイン適 応とみなすことである。具体的には，新聞記事用に提案されたゼロ代名詞照応機能付き述語項 構造解析を, 話題を限定しない雑談対話に適応させる。そして, 対話と新聞のさまざまな違い を，個々の違いを意識することなく，ドメイン適応の枠組みで包括的に吸収することを目指す。 Màrquez, Carreras, Litkowski, and Stevenson (2008), Pradhan, Ward, and Martin (2008) は, 意 味役割付与のドメイン適応に必要な要素として, 未知語対策とパラメータ分布の違いの吸収を 挙げている。本稿でも, 未知語およびパラメータ分布の観点から対話に適応させる。 そして, 新 聞記事用より対話に対して高精度な述語項構造解析を提案する。我々の知る限り，ゼロ代名詞 を多く含む対話を, 高精度に解析する述語項構造解析器は初である. 
以下, 第 2 章では, 英語意味役割付与, 日本語述語項構造解析の関連研究について述べる. 3 章では，我々が作成した対話の述語項構造データと新聞の述語項構造データを比較し，対話の 特徵について述べる。第 4 章では，今回ベースとした述語項構造解析方式の概要を述べ，第 5 章では，これを対話用に適応させる，実験を通じた評価は 6 章で述べ，第 7 章でまとめる．

\section{2 関連研究}

近年の日本語の述語項構造解析は, 教師あり学習をベースにしている。これは, 英語の意味 役割付与の考え方を参考にし，日本語の問題に当てはめたものである. 英語の意味役割付与も， 近年は意味役割として, 述語とその項（格要素ごとの名詞句）に関する情報を付与しており, 述 語項構造解析と非常に似たタスクとなっている.

\section{1 英語の意味役割付与}

英語の意味役割付与は, Gildea and Jurafsky (2002) が教師あり学習を用いた方式を提案して 以来, コーパスが整備されてきた。国際ワークショップCoNLL-2004, 2005 で行われた共有夕 スク (Carreras and Màrquez 2004, 2005)では, PropBank (Palmer, Gildia, and Kingsbury 2005) を元にした評価が行われた。 PropBank は，文に対して，述語とその項を注釈付けしたコーパ スで，文自体は，Penn Treebank（元記事はWall Street Journal）から取られているため, ここ で行われた評価も新聞記事に対するものである（このあたりの経緯は, Màrquez et al. (2008)が 整理している).

OntoNotes (Hovy, Marcus, Palmer, Ramshaw, and Weischedel 2006) は, ニュース記事, ニュー ス放送，放送における対話など，複数のジャンルを含んだコーパスである。付与された情報に は，意味役割も含んでいるが，現在は共参照解析のデータとして使用されるに留まり (Pradhan, Moschitti, and Xue 2012), 対話解析への適用はこれから期待されるところである.

意味役割付与は，タスク指向対話の意味理解にも利用される場合がある (Tur, Hakkani-Tür, and Chotimongkol 2005; Coppola, Moschitti, and Riccardi 2009) . Tur et al. (2005) は, 電話の コールセンタにおけるユーザとオペレータとの対話において，述語と項の対を素性としたコー ルタイプ分類器を構築している。ここで, 述語・項の対は, ユーザ発話を PropBank ベースの 意味役割付与器で解析することで得ている. 彼らの実験は, 素性として用いる場合は新聞記事 用の意味役割付与器でも効果があることを示したが, 本稿では, 対話における述語項構造解析 自体の精度向上を狙っている. Coppola et al. (2009) は, 同じくコールセンタ対話に対して, FrameNet (Ruppenhofer, Ellsworth, Petruck, Johnson, and Scheffczyk 2006) に準拠する意味役 割付与を行っている，彼らは，コールセンタ対話を解析するため，分野依存の意味フレームを FrameNetに追加して，スロット（フレーム要素）の穴埋めを行っている。 コールセンタ対話の 
ように，意味役割が非常に限定される場合は，フレーム追加で対応できるが, タスクを限定し ない雑談対話の場合は，分野依存フレームの追加は困難である.

なお，述語だけでなく，事態性名詞（例えば，動詞 ‘decide’に対する事態性名詞 'decision’) に対する意味役割付与の研究もある (Jiang and Ng 2006; Gerber and Chai 2012; Laparra and Rigau 2013)，事態性名詞の場合，英語でも格要素を省略して表現することがあるため（たとえ ば, “the decision”の対象格は省略されている), 日本語のゼロ代名詞と同様の問題を解決する 必要がある。

\section{2 日本語の述語項構造解析}

日本語では，奈良先端大が，述語項構造と照応デー夕を新聞記事に付与した NAISTテキス トコーパス ${ }^{1}$ を公開している (Iida, Komachi, Inui, and Matsumoto 2007; 飯田, 小町, 井之上, 乾, 松本 2010). NAIST テキストコーパスは, 毎日新聞の記事に対して, 日本語で必須格と言 われているガヨニ格の名詞句を, 各述語に付与したものである。名詞句は, 述語能動形の格に 対して付与されている。また, 名詞句は述語と同じ文内に限らず, ゼロ代名詞化されている場 合は，先行詞までさかのぼって付与されている.

述語項構造解析も, 上記コーパスを利用したものが多く提案されている (Komachi, Iida, Inui, and Matsumoto 2007; Taira, Fujita, and Nagata 2008; Imamura, Saito, and Izumi 2009; 吉川, 浅原, 松本 2013 ; 林部, 小町, 松本 2014). 日本語の場合, ゼロ代名詞が存在するため, 述語 項構造解析時に, 文をまたがるゼロ代名詞照応も解釈する場合がある（たとえば (Taira et al. 2008; Imamura et al. 2009; 林部 他 2014)).

新聞記事以外を対象とした述語項構造解析研究には, 以下のものがある。萩行, 河原, 黒橋 (2014) は，ブログなどを含むWeb テキストを対象に，特に一人称・二人称表現に焦点を当てた 照応解析法を提案している。彼らは同時に述語項構造解析も行っており，本稿のタスクと類似 している，彼らはWebテキストを解析するにあたり，外界照応（記事内に項の実体が存在しな い) を著書 (一人称), 読者 (二人称), その他の人, その他に分けるという拡張を行っている. 本稿でも, NAIST テキストコーパス（バージョン 1.5）の分類に従い, 外界照応を一人称, 二 人称, その他に分け, 項の推定を行う。また, 平, 田中, 藤田, 永田 (2014) は, ビジネスメー ルを対象とした述語項構造解析を試みている。彼らは新聞記事用の述語項構造解析器をそのま まビジネスメール解析に適用したが, 一人称・二人称外界照応は, ほとんど解析できなかった と報告している.

英語, 日本語いずれも, 現状の意味役割付与, 述語項構造解析は新聞記事のような正書法に 則って記述されたテキストやWebテキスト, メールを対象としている. 非常に限定されたタス

\footnotetext{
${ }^{1}$ http://cl.naist.jp/nldata/corpus/
} 
クを扱うコールセンタ対話の例はあるが，タスクを限定しない雑談対話を解析した際の精度や 問題点については不明である.

\section{3 雑談対話の特徵}

まず我々は，2 名の参加者による雑談対話を収集し，その対話に述語項構造データの付与を 行った，雑談対話は，参加者が自由なテーマ（話題）を設定し，キーボード対話形式で収集し た.したがって, 音声対話に含まれるような相槌や言い直しは少ない. 参加者の話題は, 食事, 旅行, 趣味, テレビ・ラジオなどである. 述語項構造アノテーションは, NAISTテキストコー パス (Iida et al. 2007; 飯田 他 2010) に準拠する形で行った. 雑談対話と, その述語項構造解析 アノテーションの例を図 1 に示す 2 .

今回作成した雑談対話コーパスと, NAIST コーパス ${ }^{3}$ の統計量を表 1 に示す。対話コーパス は, NAIST コーパスの約 $1 / 10$ のイイ゙である。また，1文/発話の長さ（形態素数）は，雑談 対話コーパスはNAIST コーパスの $1 / 3$ 程度と短い. NAIST コーパスは, 訓練, 開発, テスト に 3 分割したのに対し，対話コーパスは訓練とテストの 2 分割とした.

対話の特徴を分析するため, この 2 つのコーパスの比較を行った，表 2 は，訓練セットにお

$\mathrm{A}: \quad$ 夏は $(\mathrm{exo} 2)_{\text {ガ }}(\mathrm{exog})$ 二出かけたりしましたか?

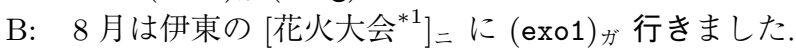

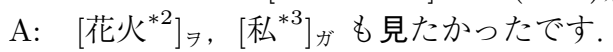

$\mathrm{A} ：$ でも，今年は $(\mathrm{exo1})_{\text {力゙ }}$ 忙しくて $(\mathrm{exo1})_{\text {ガ }}(* 2)_{\text {э }}$ 見に $(\mathrm{exo1})_{\text {ガ }}(* 2)$ 二行けませんでした.

図 1 雑談対話とその述語項構造アノテーションの例

太字は述語, [] は文内の項, () は文間の項または外界照応を表す.

また，exo1，exo2，exogはそれぞれ一人称／二人称ゼ口代名詞，それ以外の外界照応を表す．

表 1 コーパスサイズ

\begin{tabular}{l|l|c|c|rc|rc}
\hline コーパス & セット & 記事／対話数 & 文／発話数 & 形態素数 & $(1$ 文あたり $)$ & 述語数 & $(1$ 文あたり $)$ \\
\hline \multirow{2}{*}{ NAIST } & 訓練 & 1,751 & 24,283 & 664,898 & $(27.4)$ & 68,602 & $(2.83)$ \\
コーパス & 開発 & 480 & 4,833 & 136,585 & $(28.3)$ & 13,852 & $(2.87)$ \\
& テスト & 696 & 9,284 & 255,624 & $(27.5)$ & 26,309 & $(2.83)$ \\
\hline 杂誰談対話 & 訓練 & 184 & 6,960 & 61,872 & $(8.9)$ & 7,470 & $(1.07)$ \\
コーパス & テスト & 101 & 4,056 & 38,099 & $(9.4)$ & 5,333 & $(1.31)$ \\
\hline
\end{tabular}

2 対話中に一人称・二人称代名詞が陽に出現する場合, アノテータに対して exo1/exo2 との区別は指示しなかった. しかし, 述語と同一発話内ではその代名詞を項に使う場合が多く, 異なる発話の場合, 出現した代名詞をゼロ代名 詞照応先とするのではなく外界照応 (exo1/exo2) とする傾向が高かった.

3 NAIST コーパスはバージョン 1.5 を用い, 文節化の前処理を行った上で使用した. 1 文節に複数の述語が含まれ ている場合は，前方に出現した述語のみを対象とした。 
表 2 訓練セットにおける項の分布

\begin{tabular}{r|l|r|r|r|r|r|r|r}
\hline \multirow{2}{*}{ 格 } & \multirow{2}{*}{ コーパス } & \multirow{2}{*}{ 項の数 } & \multirow{2}{*}{ 係受 } & \multirow{2}{*}{ 文内ゼロ } & \multirow{2}{*}{ 文間ゼロ } & \multicolumn{3}{|c}{ 外界照応 } \\
\cline { 6 - 9 } & & & & & exo1 & exo2 & exog \\
\hline \multirow{2}{*}{$カ ゙$} & NAIST & 68,598 & $54.5 \%$ & $17.3 \%$ & $11.4 \%$ & $2.0 \%$ & $0.0 \%$ & $14.7 \%$ \\
& 雑談対話 & 7,467 & $31.8 \%$ & $7.4 \%$ & $12.6 \%$ & $23.9 \%$ & $5.6 \%$ & $18.8 \%$ \\
\hline \multirow{2}{*}{$\ni$} & NAIST & 27,986 & $89.2 \%$ & $6.9 \%$ & $3.4 \%$ & $0.0 \%$ & $0.0 \%$ & $0.4 \%$ \\
& 雑談対話 & 1,901 & $46.6 \%$ & $12.8 \%$ & $27.5 \%$ & $0.8 \%$ & $0.1 \%$ & $12.2 \%$ \\
\hline \multirow{2}{*}{ 二 } & NAIST & 6,893 & $84.7 \%$ & $10.2 \%$ & $4.3 \%$ & $0.0 \%$ & $0.0 \%$ & $0.8 \%$ \\
& 雑談対話 & 2,089 & $37.6 \%$ & $7.8 \%$ & $15.0 \%$ & $2.5 \%$ & $1.1 \%$ & $36.1 \%$ \\
\hline
\end{tabular}

ける項の分布を示したものである。各項は，述語との位置関係や文法関係などにより問題の難 しさが異なるため, 以下の 6 タイプに分類した。最初の $2 つ($ 係受および文内ゼロ）は述語と 項が同じ文に存在する場合である.

・ 係受: 述語と項が直接の係り受け関係にある場合

・文内ゼロ: 述語と項が同じ文（発話）内にあるが，直接の係り受け関係がない場合

・文間ゼロ: 述語と項が異なる文にある場合

- exo1/exo2/exog: 項が記事（対話）内に存在しない外界照応. それぞれ，一人称ゼロ 代名詞，二人称ゼロ代名詞，それ以外（一般）を表す.

これを見ると，対話ではすべての格で，係受夕イプの項が減少している，それ以外の夕イプ

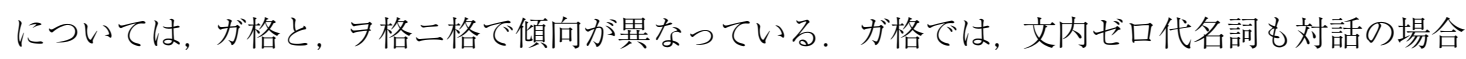
に減少し，減少分は一人称・二人称外界照応 (exo1, exo2)に割り当てられている。つまり，ガ 格では，文内の項が減少し，ゼロ代名詞が新聞に比べて頻発する。ただし，その先行詞は一人 称・二人称代名詞である可能性が高いと言うことができる. ヨ格二格では, 係受夕イプの項の 減少分は，文間ゼロ代名詞またはその他の外界照応 (exog)に割り振られている。つまり，新聞 記事では，大部分は述語と同じ文内に現れていたタ格二格の項が，対話では別の発話に現れる ことが多くなり，1文に閉じない照応解析が重要となる.

\section{4 ゼロ代名詞照応付き述語項構造解析}

\section{1 基本方式}

本稿でベースとする述語項構造解析は, Imamura et al. (2009) の方法である。これは, 新聞 記事を対象とした方法であるが, 文内に存在する項, 文間の項, 外界照応を同時に解析できる という特徴があるため, 対話の解析にも適していると判断した.

処理は，記事（対話）全体を入力とし，各文（発話）ごとに以下のステップを実行する. 
（1） 入力文を形態素・構文解析する，構文解析時には，同時に文節とその主辞を特定してお く。なお, 今回は対話コーパスに関しては, 形態素解析器 MeCab (Kudo, Yamamoto, and Matsumoto 2004)，構文解析器 CaboCha (Kudo and Matsumoto 2002) で形態素・文節 係り受け・主辞情報を自動付与した。NAIST コーパスに関しては，NAIST コーパス 1.5 付属の IPA 体系の形態素・構文情報を利用した 4 。

（2）文から述語文節を特定する。今回は評価のため，コーパスの正解述語を用いたが，対話 システム組み込みの際には，主辞が動詞，形容詞，形容動詞，名詞＋助動詞「だ」の文 節を述語文節とし，品詞パターンで決定する。

(3) 対象述語の存在する文，およびそれより前方の文から，項の候補となる文節を取得する. 文節の内容語部を候補名詞句とする。具体的には，以下の文節が候補となる。

- 対象述語の文に含まれる，内容語部が名詞句であるすべての文節を文内の候補と する。その際，述語文節との係り受け関係は考慮しない.

- 対象述語より前方の文から，文脈的に項の候補となりうる文節を加え，文間の候 補とする。詳細は 4.4 節で述べる。

- 記事内に実体を持たない疑似候補として, 外界照応 (exo1, exo2, exog) と, 任意格 のため格を必要としない (NULL) を特殊名詞句として加える.

（4）述語文節，項の候補名詞句，両者の関係を素性化し，ガ， ヨ，二格独立に，候補からもっ とも各格にふさわしい名詞句を選択器で選択する（図 2).

本稿では, Imamura et al. (2009) の方式から, 若干の変更を行っている. 変更点は以下のと おりである。

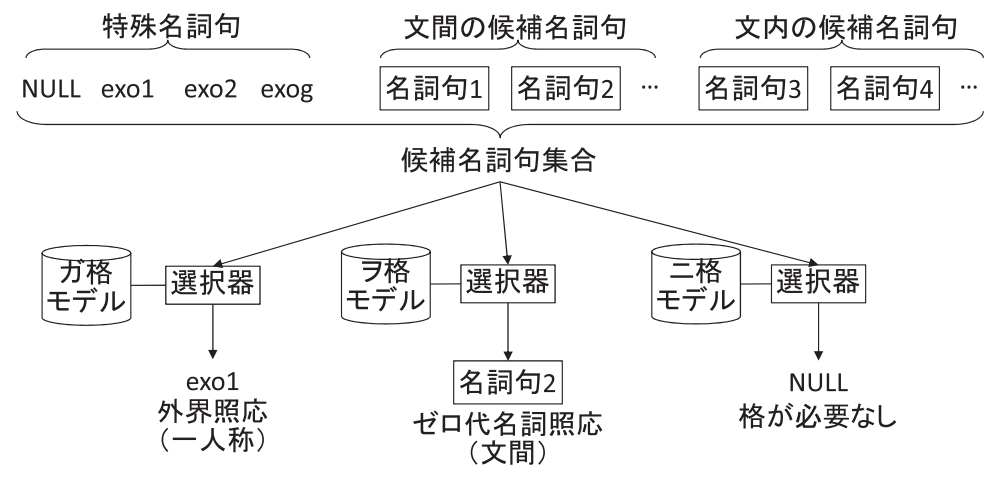

図 2 項選択の例

\footnotetext{
${ }^{4}$ NAIST コーパス 1.5 は, IPA 体系の形態素，文節，主辞情報を含んだ形で配布されている。京都大学テキストコー パス 4.0 （http://nlp.ist.i.kyoto-u.ac.jp/index.php?京都大学テキストコーパス）と, 毎日新聞 1995 年版記事デー 夕を合成することで，係り受け情報を含む完全な NAIST コーパスが構成できるようになっている.
} 
- Imamura et al. (2009)では, 特殊名詞句は 1 種類（NULL のみ）であったが, 本稿では 4 種類 (NULL, exo1, exo2, exog) に拡張した. 萩行他 (2014) は, 外界照応を含む一人称, 二人称ゼロ代名詞（論文では著者・読者表現）の照応解析を行うことで，それ以外のゼ ロ代名詞の照応解析精度も向上したと報告している。本稿でも, 特殊名詞句の種別を増 やすこととする.

・素性が異なる。本稿では, 4.3 節で述べる素性を使用したが, これは Imamura et al. (2009) の基本素性を拡張, 追加したものである。 また, 文脈を考慮する素性 (文献では SRLOrder, Used）は使用せず，簡略化した。これは，文脈管理を外部モジュールに任せるためで, 詳細は 4.4 で述べる。

・ 係り受け言語モデル（5.2.2 節参照）を 1 種類から 3 種類に拡張した.

\section{2 選択器のモデル}

選択器のモデルは, 最大エントロピー分類に基づく，具体的には，選択器は記事内の述語 $v$ ごとに，候補名詞句集合 $\mathbf{N}$ から，以下の式を満たす名詞句 $\hat{n}$ を選択する.

$$
\begin{aligned}
\hat{n} & =\underset{n_{j} \in \mathbf{N}}{\operatorname{argmax}} P\left(d\left(n_{j}\right)=1 \mid X_{j} ; M_{c}\right) \\
P\left(d\left(n_{j}\right)=1 \mid X_{j} ; M_{c}\right) & =\frac{1}{Z_{c}(X)} \exp \sum_{k}\left\{\lambda_{c k} f_{k}\left(d\left(n_{j}\right)=1, X_{j}\right)\right\} \\
Z_{c}(X) & =\sum_{n_{j} \in \mathbf{N}} \exp \sum_{k}\left\{\lambda_{c k} f_{k}\left(d\left(n_{j}\right)=1, X_{j}\right)\right\} \\
X_{j} & =\left\langle n_{j}, v, A\right\rangle
\end{aligned}
$$

ただし， $n$ は 1 つの候補名詞句, $\mathbf{N}$ は候補名詞句集合, $d\left(n_{j}\right)$ は, 名詞句 $n_{j}$ が項となったとき のみ 1 となる関数, $M_{c}$ は格 $c$ (ガ, ヨ, 二のいずれか) のモデルである. また, $f_{k}\left(d\left(n_{j}\right)=1, X_{j}\right)$ は素性関数, $\lambda_{c k}$ は格毎の素性関数の重み, $v, A$ はそれぞれ述語, および形態素・構文解析済み の記事全体である.

訓練時には，ある述語の候補名詞句集合ごとに，正解の名詞句と，それ以外のすべての候補 名詞句との事後確率差を大きくするように学習する. 具体的には, 以下の損失関数を最小化す るモデル $M_{c}$ を，格ごとに学習する.

$$
\ell_{c}=-\sum_{i} \log P\left(d\left(n_{i}\right)=1 \mid X_{i} ; M_{c}\right)+\frac{1}{2 C} \sum_{k}\left\|\lambda_{c k}\right\|^{2}
$$

ただし， $n_{i}$ は，訓練セットの $i$ 番目の述語に対する正解名詞句， $X_{i}$ は，訓練セットの $i$ 番目の 正解名詞句, 述語, 記事の組 $\left\langle n_{i}, v_{i}, A_{i}\right\rangle, C$ は過学習を制御するためのハイパーパラメータで, 開発セットにおける精度が最高になるように，あらかじめ設定しておく。式 (3)で，述語の候 
補名詞句集合毎に正規化を行っているため，(5) 式では，候補名詞句集合から，正解名詞句が選 ばれた時に確率 1.0 , それ以外の名詞句では確率 0.0 に近づくようにモデルが学習される.

\section{3 素性}

選択器で使用する素性に関しては，英語の意味役割付与に関する研究（たとえば Gildea and Jurafsky (2002)）と同様に，(1) 述語に関する素性，(2) 名詞句に関する素性，(3) 両者の関係に 関する素性を使用する。詳細を表 3 に示す.

二值の素性関数は，テンプレートの引数が完全一致したときのみ 1 ，それ以外では 0 を返す関 数である。たとえばPred 素性において，主辞形態素の見出しが 1 万種類あったとすると， 1 万 の二值関数が定義され，主辞形態素の見出しと一致した関数だけが 1 を返す，実数值の素性関

表 3 素性テンプレート一覧

\begin{tabular}{|c|c|c|c|}
\hline 種別 & 素性名 & 值 & 備考 \\
\hline \multirow{5}{*}{ 述語 } & Pred & 二值 & 主辞形態素の見出し \\
\hline & PType & 二値 & $\begin{array}{l}\text { 述語の種別．動詞 (VERB), 形容詞 (ADJ), ダ文（形容動詞を含む) } \\
\text { (COPULA)のいずれか }\end{array}$ \\
\hline & Voice & 二值 & $\begin{array}{l}\text { 受身, 使役の助動詞を含む場合, その見出し. それ以外は「能動 } \\
\text { 形」 }\end{array}$ \\
\hline & Suffix & 二值 & 主節の述語文節の機能語列. 発話行為を反映させるための素性 \\
\hline & Frame & 二値 & 必須格情報辞書引き結果． 格を必要とする場合 1 , 不必要な場合 0 \\
\hline \multirow{5}{*}{ 名詞句 } & Noun & 二值 & 名詞句主辞形態素の見出し \\
\hline & Particle & 二值 & $\begin{array}{l}\text { 文節の機能語主辞. 特殊名詞句の場合は NULL. 係助詞と格助詞が } \\
\text { 併存している場合は格助詞優先（例：「には」は「に」を優先). }\end{array}$ \\
\hline & NType & 二值 & $\begin{array}{l}\text { 特殊名詞句の場合はその名詞句. 記事/対話内に名詞句が存在す } \\
\text { る場合はNP }\end{array}$ \\
\hline & Surround & 二值 & $\begin{array}{l}\text { 名詞句周辺形態素の品詞. ウインドウサイズを } \pm 2 \text { としている. つ } \\
\text { まり, 前方 } 2 \text { 形態素の品詞と, 後方 } 2 \text { 形態素の品詞の計 } 4 \text { 素性. }\end{array}$ \\
\hline & $\log P(c \mid n)$ & 実数 & $\begin{array}{l}\text { 係り受け言語モデル．名詞句 } n \text { から見た格 } c \text { の生成確率. } n \text { が特 } \\
\text { 殊名詞句だった場合は素性を作成しない }\end{array}$ \\
\hline \multirow{5}{*}{$\begin{array}{l}\text { 述語と名詞 } \\
\text { 句の関係 }\end{array}$} & PhPosit & 二值 & $\begin{array}{l}\text { 述語文節と名詞句文節の文節間距離. 整数值を個別のクラスとし } \\
\text { て扱う. 異なる文，または外界照応の場合は NULL }\end{array}$ \\
\hline & Syn & 二值 & $\begin{array}{l}\text { 述語文節と名詞句文節の係り受けパス，異なる文，または外界照 } \\
\text { 応の場合は NULL }\end{array}$ \\
\hline & Speaker & 二值 & $\begin{array}{l}\text { 述語文節の発話者と, 名詞句文節の発話者が同じか？ SAME, OTHER } \\
\text { のいずれか }\end{array}$ \\
\hline & $\log P(n \mid c, v)$ & 実数 & $\begin{array}{l}\text { 係り受け言語モデル．述語 } v, \text { 格 } c \text { から見た名詞句 } n \text { の生成確率. } \\
n \text { が特殊名詞句だった場合は素性を作成しない }\end{array}$ \\
\hline & $\log P(v \mid c, n)$ & 実数 & $\begin{array}{l}\text { 係り受け言語モデル．名詞句 } n \text {, 格 } c \text { から見た述語 } v \text { の生成確率. } \\
n \text { が特殊名詞句だった場合は素性を作成しない }\end{array}$ \\
\hline
\end{tabular}


数は, テンプレートの引数に応じた実数を返す。なお,これらは名詞句の選択用モデルの素性 であるので，名詞句 Noun と，すべての二值素性を組み合わせた素性も使用している．

本稿で特徵的な素性は, 大規模データから自動構築した必須格情報 Frame と係り受け言語モ デル（3 種類）であるが，これらについては 5.2 節で述べる.

\section{4 文脈処理}

本稿では，人とコンピュータの対話システム実現のための解析器を想定している。この対話 システムは, ユーザとシステムが交互に発話するもので, システムに組み込まれた対話管理部 が両者の発話履歴や，現在話されている話題（焦点）を管理する。述語項構造解析部はユーザ 発話を解析し， 発話生成部がシステム発話を生成するというものである.

従来の述語項構造解析器も, 現在の解析対象文より以前の文を文脈として利用し, ゼロ代名 詞照応解析に利用している. Imamura et al. (2009) は, 解析器内部で以前の文や話題（焦点）の 管理（これを文脈管理と呼ぶ）を行っていた。しかし，述語項構造解析器内部で文脈管理を行 うより，対話システムの対話管理部が文脈管理を行った方が，ユーザ発話とシステム発話を協 調的に管理できる可能性が高い. 本稿ではこのように考え, 文脈管理は外部モジュールの担当 と位置付ける。そして評価用に，新聞記事と対話で同じ文脈管理方法を使用する。なお，本稿 の方式は, 選択器に与える文間の候補名詞句を取捨選択することによって文脈の制御を行って いるので，候補名詞句を外部モジュールから陽に与えることで，文脈管理方法を変更すること ができる.

今回使用した文脈管理方法は，具体的には以下のとおりである.

・対象述語の発話より以前の発話をさかのぼり, 他の述語を含む発話（これを有効発話と 呼ぶ）を見つける。これは，述語を含まない発話を無視するためである.

- 有効発話と対象述語の発話の間に出現した全名詞句と, 有効発話の述語で項として使わ れた名詞句（有効発話内の場合もあれば，それ以前の発話の名詞句の場合もある）を候 補として加える。項として使われた名詞句は, その後も繰り返し使われることが多く, これに制限することで，効率的に候補を削減することができるという観察結果に基づく (Imamura et al. 2009). また, 項として使われている限り, さかのぼる文数に制限がない ため，広い文脈を見ることができる。

\section{5 雑談対話への適応}

前節で述べた方法は，対話，新聞記事に共通の処理である。これを対話解析に適したものに するため, パラメータの適応，および大規模コーパスから自動獲得した知識の適用を行う. 


\section{1 モデルパラメータの適応}

NAIST コーパスと対話コーパスの項分布の差異は, 選択器のモデルパラメータをドメイン適応 することで調整する。本稿では，モデルパラメータの適応手法として，素性空間拡張法 (Daumé 2007) を用いる。これは，素性空間を 3 倍に拡張することで, ソースドメインデータをターゲッ トドメインの事前分布とみなすのと同じ効果を得る方法である.

具体的には，以下の手順で選択器のモデルを学習・適用する.

（1）まず，素性空間を共通，ソース，ターゲットの 3 つに分割する.

(2) NAIST コーパスをソースドメインデータ, 対話コーパスをターゲットドメインデータと みなし, NAIST コーパスから得られた素性を共通とソース空間にコピーして配置する。 対話コーパスから得られた素性は共通とターゲット空間にコピーして配置する。

（3）拡張された素性空間上で，通常通りパラメータ推定を行う。結果，ソース・ターゲット データ間で無矛盾な素性は，共通空間のパラメータが強調され（絶対值が大きくなる）, ドメインに依存する素性は, ソースまたはターゲット空間のパラメータが強調される.

（4）選択器が項を選択する際は，ターゲット空間と共通空間の素性だけ用いる。この空間の パラメータは, ターゲットドメインに最適化されているだけでなく, ソースドメインデー 夕だけに現れた共通空間の素性も利用して，項選択ができる。

\section{2 大規模コーパスからの知識獲得}

本稿では, 訓練コーパスに含まれない未知語への対策として, 大規模コーパスから自動獲得し た 2 種類の知識を利用する。 どちらも大規模平文コーパスを自動解析して, 集計やフィルタリ ングをすることで獲得する (河原, 黒橋 2005; Sasano, Kawahara, and Kurohashi 2008; Sasano, Kawahara, Kurohashi, and Okumura 2013) ，当然誤りも含むが，新出語に対しても，ある程度 の確かさで情報を与えることができる。これらを選択器の素性として使い，モデルを学習する ことにより，情報の信頼度に応じたパラメータが学習される．

\subsection{1 必須格情報（Frame 素性）}

格フレームは，述語の必須格と，その格を埋める名詞句の種類（通常は意味クラス）を保持 するフレーム形式の情報で, 述語項構造解析や意味役割付与の重要な手がかりとなる. 本稿で 使う必須格情報は，格フレームのうち，格が必要か否か（必須格か任意格か）だけについて情 報を与える辞書である。

本稿の必須格情報は，大規模平文テキストコーパスから，以下の方法で自動構築する．これ は, (1) 項が述語と直接係り受け関係にある場合, 述語に対する項の格は, 項の名詞句に付随す る格助詞と一致することが多い, (2) 必須格なら, その格の出現率は他の述語より平均的に高 
い5，という仮定をもとにしている.

- まず, 本稿の述語項構造解析と同様 (4.1 節参照) に, 平文を形態素・構文解析し, 品詞 パターンで述語文節とその主辞を特定する ${ }^{6}$.

・述語文節に直接係る文節を取得し，機能語部に格助詞を持つ文節だけを残す。もし，そ のような文節が 1 つ以上あるなら，その述語を集計対象として，述語頻度，格助詞の出 現頻度を集計する。

・述語に関しては, 高頻度述語から順番に, 最終的な辞書サイズを考慮して選択する. 個々 の格に関しては，以下の条件をすべて満たす格を，必須格とみなす．

- 〈述語 $v$, 格 $c\rangle$ が, 対数尤度比検定において, 危険率 $0.1 \%$ 以下で有意に多く共起し ていること（ $p \leq 0.001 ;$ 対数尤度比 $\geq 10.83)$.

- 各述語における格 $c$ の出現率が，全述語における格の出現率（平均）より $10 \%$ 以 上高いこと.

以上の方法で, 2 種類の必須格情報辞書を作成した。一つは，ブログ約 1 年分（約 23 億文. 以下 $\operatorname{Blog} コ$ コイ゚と呼ぶ）から，48 万述語の情報を獲得した（これを $\mathrm{Blog}$ 辞書と呼ぶ）。もう 一つは新聞記事 12 年分（約 770 万文. 以下 News コーパスと呼ぶ）から約 20 万述語の情報を 獲得した（同 News 辞書).

表 4 は, 杂誰談対話コーパス訓練セットの正解述語項構造と必須格情報辞書を比較し, 必須格 情報辞書の述語カバー率と格毎の精度を算出したものである。述語カバー率は，対話コーパス に出現した述語が必須格情報辞書に含まれている場合，カバーしたと判断した，結果，Blog 辞

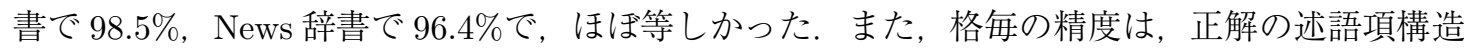
に格が付与されているか否かと，必須格情報上の必須格性が一致しているかどうかを測定した

表 4 必須格辞書の述語カバー率と精度（対話コーパス訓練セットで測定した場合）

\begin{tabular}{|c|c|c|c|c|c|c|}
\hline \multirow{2}{*}{ 必須格情報辞書 } & \multirow{2}{*}{ 獲得述語数 } & \multirow{2}{*}{ 述語カバー率 } & \multicolumn{4}{|c|}{ 必須格情報の格毎の精度 } \\
\hline & & & 格 & 格が必要な場合 & 格が不要な場合 & 全体 \\
\hline \multirow{3}{*}{ Blog 辞書 } & \multirow{3}{*}{480,704} & \multirow{3}{*}{$98.5 \%$} & ガ & $40.2 \%$ & $66.7 \%$ & $40.2 \%$ \\
\hline & & & Э & $84.1 \%$ & $95.1 \%$ & $91.7 \%$ \\
\hline & & & 二 & $51.4 \%$ & $93.9 \%$ & $79.3 \%$ \\
\hline \multirow{3}{*}{ News 辞書 } & \multirow{3}{*}{198,684} & \multirow{3}{*}{$96.4 \%$} & ガ & $36.8 \%$ & $66.7 \%$ & $40.2 \%$ \\
\hline & & & ᄏ & $83.4 \%$ & $95.2 \%$ & $91.7 \%$ \\
\hline & & & 二 & $47.4 \%$ & $94.9 \%$ & $78.6 \%$ \\
\hline
\end{tabular}

5 ゼロ代名詞化されている場合は, 項が述語と同じ文に現れないため, 必須格であっても，出現率は $100 \%$ にはなら ない，そのため，出現した/しないという二值では，必須格性は判断できないと考えた．

6 ただし，受身・使役の助動詞が述語文節に含まれる場合は，別述語として扱うように，助動詞と合成した述語を新 たに生成した。 
もので, Blog 辞書, News 辞書でほほ同じ傾向を示している，格毎に見ると，ガ格の精度が低 いが，これは，雑談対話コーパスでは，ほぼすべての述語に対してガ格が付与されている（つ まり，ガ格が必須）にも関わらず，Blogコーパスや News コーパスではそれがゼロ代名詞化さ れているため，自動獲得では必須格とは判断できなかったためである。 ヨ格の全体精度は $91 \%$ 以上と，格によっては高い精度を持つ辞書となっている.

\subsection{2 係り受け言語モデル}

係り受け言語モデル (language model; LM) は, 三つ組〈述語 $v$, 格 $c$, 名詞句 $n\rangle$ の共起のしや すさを表現するモデルである，頻出表現に高いスコアを与えることによって，出現する単語間 に意味的関連が存在することを表現する意図がある。ここでは, 述語 $v$, 格 $c$, 名詞句 $n$ それぞ れの生成確率を n-gram モデルで算出し, 選択器の識別モデルで全体最適化を行う。具体的に は, 以下の実数值を算出し，表 3 の係り受け言語モデル素性の素性関数值として使用する。そ の結果, 選択器は, 候補名詞句集合から, 頻出表現に含まれる名詞句 $n$ を優先して選択するこ とになる。なお，未知語を表す特殊単語くunk>を含む確率で補正してる理由は，対数確率 $(-\infty$ 〜0.0の範囲）を正の值に補正するためである.

- $\log P(n \mid c, v)-\log P(<\mathrm{unk}>\mid c, v)$

- $\log P(v \mid c, n)-\log P(v \mid c,<$ unk $>)$

- $\log P(c \mid n)-\log P(c \mid<u n k>)$

本稿の係り受け言語モデルは, Imamura et al. (2009) が 1 種類 $(\log P(n \mid c, v)$ 相当) のみ使用 していたのに対し，識別モデルが互いに依存しあう素性を含めることができるという特徵を利 用し， 3 種類に拡張している。 また, 述語 $v$ から見た格 $c$ の生成確率 $(\log P(c \mid v))$ は, 述語ごと に格を必要とする度合であり, 必須格情報と重なるため, 係り受け言語モデルからは除外した。

3 種類の係り受け言語モデルは, 5.2.1節で抽出した述語, 格, 名詞句を集計し, SRILM (Stolcke, Zheng, Wang, and Abrash 2011) でバックオフモデルを構築した.

係り受け言語モデルも，Blogコーパス，Newsコーパスからそれぞれ作成した。これを，そ れぞれ Blog 言語モデル, News 言語モデルと呼ぶ。言語モデルのカバー率を, 杂隹談対話コーパ ス訓練セットに出現する三つ組が係り受け言語モデルの元になった三つ組に含まれるかどうか で測定すると, Blog 言語モデルの場合, $76.4 \%$ カバーしていた。一方, Newsの言語モデルの 場合，カバー率は $38.3 \%$ だった． News 言語モデルに比べ， Blog 言語モデルは対話コーパスに 出現する係り受けの三つ組のカバレッジが高い7.

7 バックオフモデルの場合, モデル中に三つ組が存在しなくても, 二つ組を組み合わせるなどして, 素性関数として は何らかの值を返すことができる。 


\section{6 実験}

本節では, 表 1 に示したコーパスを用い, 対話における述語項構造解析の精度を, パラメー 夕適応, 大規模コーパスから自動獲得した知識の効果という観点から評価する。評価はすべて 雑談対話コーパステストセットで行う。評価指標には, 項の適合率, 再現率から算出した F 值 を用いる。

\section{1 実験 1: パラメータ適応の効果}

まず，パラメータ適応の効果を測定するため，訓練方法を変えた 3 方式の比較を行った．表 5 の (a), (b), (c) カラムがその結果で, それぞれ (a) 素性空間拡張によるドメイン適応を行っ た場合（適応，提案法)，(b) NAIST コーパスだけで訓練した場合（NAIST 訓練．従来の新聞 記事用解析に相当)，(c) 対話コーパスだけで訓練した場合（対話訓練）を表す.

まず，(a) 適応と (b) NAIST 訓練を比較すると, 多くの場合, 適応の方が有意に精度がよい という結果になった（の記号が有意差ありを表す），特に合計の精度では，すべての格で適応が

表 5 対話テストセットにおける方式・必須格情報・係り受け言語モデルごとの F 值

\begin{tabular}{|c|c|c|c|c|c|c|c|}
\hline 格 & タイプ & 項の数 & $\begin{array}{c}\text { (a) 適応 } \\
\text { 必須格: Blog } \\
\text { LM: Blog }\end{array}$ & $\begin{array}{c}\text { (b) NAIST 訓練 } \odot \\
\text { 必須格: Blog } \\
\text { LM: Blog }\end{array}$ & $\begin{array}{c}\text { (c) 対話訓練 } \diamond \\
\text { 必須格：Blog } \\
\text { LM: Blog }\end{array}$ & $\begin{array}{c}\text { (d) 適応 } \\
\text { 必須格：News } \\
\text { LM: Blog }\end{array}$ & $\begin{array}{c}\text { (e) 適応 } \\
\text { 必須格: : Blog } \\
\text { LM: News \& }\end{array}$ \\
\hline \multirow{7}{*}{ ガ } & $\begin{array}{l}\text { 係受 } \\
\end{array}$ & 1,811 & $\mathbf{8 3 . 3} \% \triangleright \diamond$ & $77.6 \%$ & $82.7 \%$ & $83.0 \%$ & $82.7 \%$ \\
\hline & 文内ゼロ & 511 & $37.4 \%$ & $\mathbf{4 3 . 7} \% \odot$ & $36.6 \%$ & $36.5 \%$ & $38.1 \%$ \\
\hline & 文間ゼロ & 767 & $8.6 \%$ & $9.1 \%$ & $9.0 \%$ & $8.3 \%$ & $4.5 \%$ \\
\hline & exo1 & 1,193 & $70.2 \% \odot$ & $13.5 \%$ & $69.9 \%$ & $70.1 \%$ & $\mathbf{7 0 . 3} \%$ \\
\hline & exo2 & 281 & $46.8 \% \triangleright \diamond$ & $0.0 \%$ & $43.1 \%$ & $47.2 \%$ & $46.8 \%$ \\
\hline & exog & 767 & $46.8 \% \varnothing$ & $32.5 \%$ & $27.9 \%$ & $47.2 \%$ & $47.7 \%$ \\
\hline & 合計 & 5,330 & $61.5 \% \varnothing$ & $44.4 \%$ & $61.1 \%$ & $61.4 \%$ & $61.4 \%$ \\
\hline \multirow{7}{*}{ F } & 係受 & 614 & 84.2\% $\diamond \diamond ~ \&$ & $78.6 \%$ & $81.5 \%$ & $84.2 \%$ & $82.4 \%$ \\
\hline & 文内ゼロ & 149 & $42.9 \% \varnothing$ ధ. & $27.1 \%$ & $45.0 \%$ & $38.9 \%$ & $34.3 \%$ \\
\hline & 文間ゼロ & 399 & $30.4 \% 8$ \& & $0.5 \%$ & $30.9 \%$ & $29.4 \%$ & $24.3 \%$ \\
\hline & exo1 & 19 & $0.0 \%$ & $0.0 \%$ & $0.0 \%$ & $9.5 \%$ & $10.0 \%$ \\
\hline & exo2 & 7 & $0.0 \%$ & $0.0 \%$ & $0.0 \%$ & $0.0 \%$ & $0.0 \%$ \\
\hline & exog & 98 & $25.6 \% \odot$ & $0.0 \%$ & $\mathbf{2 7 . 9} \%$ & $25.2 \%$ & $25.6 \%$ \\
\hline & 合計 & 1,286 & $\mathbf{5 9 . 0} \% \varnothing \quad \boldsymbol{q}$ & $51.6 \%$ & $58.9 \%$ & $58.4 \%$ & $56.0 \%$ \\
\hline \multirow{7}{*}{$=$} & $\begin{array}{l}\text { 係受 } \\
\end{array}$ & 566 & $80.5 \% \diamond \diamond$ & $54.0 \%$ & $79.0 \%$ & $80.1 \%$ & $80.7 \%$ \\
\hline & 文内ゼロ & 70 & $\mathbf{2 0 . 7} \% \odot$ \& & $0.0 \%$ & $20.0 \%$ & $20.7 \%$ & $11.8 \%$ \\
\hline & 文間ゼロ & 169 & $14.6 \% \varnothing$ & $0.0 \%$ & $14.8 \%$ & $14.4 \%$ & $13.4 \%$ \\
\hline & exo1 & 32 & $0.0 \%$ & $0.0 \%$ & $0.0 \%$ & $0.0 \%$ & $0.0 \%$ \\
\hline & exo2 & 4 & $0.0 \%$ & $0.0 \%$ & $0.0 \%$ & $0.0 \%$ & $0.0 \%$ \\
\hline & exog & 265 & $\mathbf{4 5 . 4 \%} \triangleright \diamond \diamond$ & $0.0 \%$ & $43.1 \%$ & $44.0 \%$ & $44.9 \%$ \\
\hline & 合計 & 1,106 & $\mathbf{5 8 . 6 \%} \oslash \diamond$ & $32.2 \%$ & $57.2 \%$ & $58.2 \%$ & $58.4 \%$ \\
\hline
\end{tabular}

表中の太字は, 全方式のうち, F 值最高を指す。また, 記号 $\nabla, \diamond, \boldsymbol{中}, \boldsymbol{中}$ は，(a) と，それぞれ (b) (c) (d) (e)の比較で，有意によかったものを表す，有意差検定は，ブートストラップ再サンプリング法（1,000 回 測定）を使用し，危険率を $5 \%$ とした。 
有意に勝っている. タイプ別の精度を見ると, 特徵的なのは, ガ格の一人称, 二人称外界照応 (exo1, exo2) である.これらはガ格の項のうちの約 $28 \%$ を占めているが, exo1 で $70.2 \%$, exo2 で 46.8\%の F 值で解析可能となった。他にも， ヨ格二格の文間ゼロ, exogなど, NAIST 訓練で はほとんど解析できなかったタイプの項が解析できるようになった.

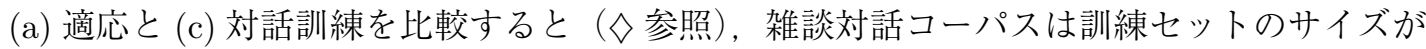
小さいにも関わらず，両者の精度が近くなった，適応の合計精度が有意に良かったのは，二格 のみである。これには 2 つの理由が考えられる。

・対話コーパス量が十分であり, NAIST コーパスの影響をほとんど受けない場合.

- 適応がNAIST コーパスの知識を活かしきっていない場合. 言い換えると, NAIST コーパ スに出現する言語現象と, 対話に出現する言語現象に重なりが少ないため, NAIST コー パスが影響しない場合.

前者の場合，コーパスサイズに対する学習曲線が今回のデータ量で飽和していることで検証 できる。本稿で作成した対話コーパスはNAIST コーパスの約 $1 / 10$ の訓練セットであるため, 学習曲線は描かなかった。後者の場合, 対話コーパスサイズを大きくすると, 述語項構造解析 の精度も向上する，今後，さらに対話コーパスを作成し，検証する必要がある.

\section{2 実験 2: 自動獲得知識の比較}

表 5 の (a) (d) (e) は，提案方法（適応）の評価結果である。ただし，必須格情報および係り 受け言語モデルは，それぞれ (a) $\langle\mathrm{Blog}, \mathrm{Blog}\rangle, \quad(\mathrm{d})\langle\mathrm{News}, \mathrm{Blog}\rangle, \quad(\mathrm{e})\langle\mathrm{B} \log , \mathrm{News}\rangle$ に変えて評 価している。

まず，必須格情報辞書を (a) Blogから (d) Newsに変えた場合を比較すると（参照)，両者 の間で有意差があったのは， フ格の文内ゼロのみで, ほぼすべての場合で有意差はなかった。

一方，係り受け言語モデルを (a) Blog から (e) Newsに変更すると

(o 参照), 若干精度に差が 出た。特に，文法関係より意味関係を重視する文内・文間ゼロでは，有意に精度が悪化したも のが多く（ガ格の文間ゼロ， ヨ格の文内・文間ゼロ，二格の文内ゼロ），その結果，合計の精度 でも， タ格は約 3 ポイント低下した。 ゼロ代名詞照応のように，述語と項の間に文法的な関係 が弱い場合，意味的関連性を共起から判断する係り受け言語モデルが相対的に重要となる。 そ のため, 係り受け言語モデルの違いが精度に影響しやすい.

図 3 は, 適応方式において, それぞれ必須格情報辞書の述語カバー率, 係り受け言語モデル の三つ組〈述語 $v$, 格 $c$, 名詞句 $n\rangle$ のカバー率を意図的に変化させて, 述語項構造解析の $\mathrm{F}$ 值を 測定したグラフである，必須格情報，係り受け言語モデルともに，Blogコーパスから作成した ものを利用した。必須格情報のカバー率は高頻度述語から順番に, 杂誰談対話コーパス訓練セッ トの述語のカバー率が指定した割合になるまで選択した，係り受け言語モデルの三つ組は，同 じく雑談対話コーパス訓練セット上での三つ組カバー率が指定した割合になるまで，ランダム 
（a）必須格情報

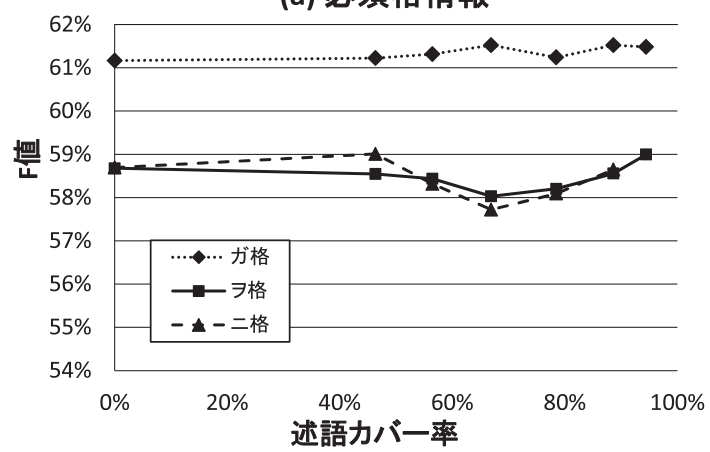

(b) 係り受け言語モデル

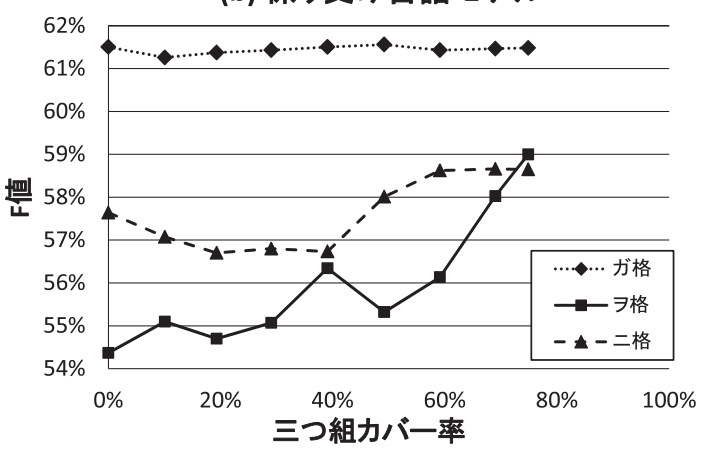

図 3 自動獲得知識のカバレッジと述語項構造解析精度

に選択した8．グラフに示した $\mathrm{F}$ 值は，格の合計である.

図 3(a) をみると，必須格情報については，格の種類にかかわらず，述語カバー率を変えても ほぼ同じ精度となった。この理由を分析したところ, テストセットに出現する大部分の述語は, 訓練セットに出現したためであった，実際，雑談対話テストセットに出現する 5,333 述語のう ち, 4,442 述語 $(83.3 \%)$ は雑談対話コーパス訓練セット，またはNAIST コーパス訓練セットに 出現していた。つまり，訓練セットだけでテストセットの大部分をカバーできており，それ以 外の述語しか, 必須格情報が有効に作用しなかったため, カバー率の影響がほとんど出なかっ たと考えられる。

一方，係り受け言語モデルの三つ組は，雑談対話テストセットに出現した 5,056 組（外界照

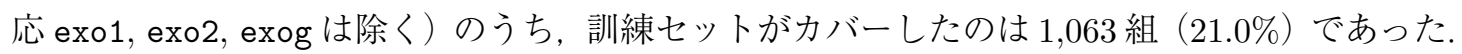
そのため, 図 3(b) のように, 係り受け言語モデルのカバー率を上げると, 述語項構造解析の精 度も向上した。ただし，ガ格に関しては，自動獲得元コーパスにおいてもガ格がゼロ代名詞化 され，自動獲得精度が十分ではなかったため，カバー率を上げても述語項構造解析精度は向上 しなかった。

まとめると，自動獲得した知識は，訓練コーパスのカバレッジが高い部分では効果がほとん どなく，低い部分を補完するのに有効である。そのため, 杂倠談対話のように幅広い話題を対象 とする対話には適している。

\section{3 雑談対話コーパスを使用せずに適応する場合}

ドメイン適応のシチュエーションとして, 新聞記事コーパスしか存在しない状況で, 述語項 構造解析器を対話に適応させなければならない場合が考えられる。本節では, NAISTテキスト

8 係り受け言語モデルは, 確率モデルであるため, 三つ組の頻度を基準に取捨選択すると，確率分布が変化する，確 率分布を変えずにカバー率を変えるため, ランダム選択とした。 
コーパスと自動獲得知識だけでモデルを学習し, 自動獲得知識がどの程度有効か, 検証する.

表 6 は, NAIST コーパス訓練セットでモデルを学習し, 雑談対話コーパステストセットで F 值 を測定した結果である。ただし，自動獲得知識の組み合わせ〈必須格情報,係り受け言語モデル〉 は，(b) $\langle\mathrm{Blog}, \mathrm{Blog}\rangle,(\mathrm{b}-1)\langle な し, B \log \rangle,(\mathrm{b}-2)\langle\mathrm{Blog}$, なし〉, (b-3)〈なし,なし〉に変えている。(b) は，表 5 の再掲である。

これを見ると，多くの場合で (b)〈Blog, Blog〉が有意に勝っており，自動獲得知識が有効に作 用していると言ってよい.

しかし，これらはすべて NAIST 訓練の結果であり，ほとんど（またはまったく）解析できな かったタイプの項（たとえば，ガ格の exo1，exo2，ヲ格の文間ゼロ，二格の文内・文間ゼロ）は， 必須格情報辞書，係り受け言語モデルをどのように変えようとも，ほとんど解析できない状況 には変わりはなかった。

表 6 NAIST 訓練における自動獲得知識の効果（自動獲得知識は Blog）

\begin{tabular}{|c|c|c|c|c|c|c|}
\hline 格 & タイプ & 項の数 & $\begin{array}{l}\text { (b)NAIST 訓練 } \\
\text { 必須格：Blog } \\
\text { LM: Blog }\end{array}$ & $\begin{array}{c}\text { (b-1)NAIST 訓練 } \\
\text { 必須格：なし } † \\
\text { LM: Blog } \\
\end{array}$ & $\begin{array}{c}\text { (b-2)NAIST 訓練 } \\
\text { 必須格：Blog } \\
\text { LM:なし } \\
\end{array}$ & 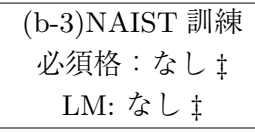 \\
\hline \multirow{7}{*}{ ガ } & 倸受 & 1,811 & $\mathbf{7 7 . 6} \% \dagger \S \ddagger$ & $76.6 \%$ & $76.5 \%$ & $74.3 \%$ \\
\hline & 文内ゼロ & 511 & $\mathbf{4 3 . 7} \% \oint \ddagger$ & $43.4 \%$ & $41.8 \%$ & $40.4 \%$ \\
\hline & 文間ゼロ & 767 & $\mathbf{9 . 1} \% \dagger \S \ddagger$ & $7.1 \%$ & $6.5 \%$ & $5.2 \%$ \\
\hline & exo1 & 1,193 & $13.5 \%$ & $13.2 \%$ & $13.4 \%$ & $13.1 \%$ \\
\hline & exo2 & 281 & $0.0 \%$ & $0.0 \%$ & $0.0 \%$ & $0.0 \%$ \\
\hline & exog & 767 & $32.5 \% \dagger$ & $31.2 \%$ & $32.3 \%$ & $31.7 \%$ \\
\hline & 合計 & 5,330 & $\mathbf{4 4 . 4} \% \dagger \S \ddagger$ & $43.5 \%$ & $43.4 \%$ & $42.5 \%$ \\
\hline \multirow{7}{*}{ ᄏ } & 倸受 & 614 & $\mathbf{7 8 . 6} \% \dagger \S \ddagger$ & $75.4 \%$ & $73.2 \%$ & $67.7 \%$ \\
\hline & 文内ゼロ & 149 & $\mathbf{2 7 . 1} \% \dagger \S \ddagger$ & $17.4 \%$ & $10.6 \%$ & $6.1 \%$ \\
\hline & 文間ゼロ & 399 & $0.5 \%$ & $0.5 \%$ & $0.5 \%$ & $0.0 \%$ \\
\hline & exo1 & 19 & $0.0 \%$ & $0.0 \%$ & $0.0 \%$ & $0.0 \%$ \\
\hline & exo2 & 7 & $0.0 \%$ & $0.0 \%$ & $0.0 \%$ & $0.0 \%$ \\
\hline & exog & 98 & $0.0 \%$ & $0.0 \%$ & $0.0 \%$ & $0.0 \%$ \\
\hline & 合計 & 1,286 & $\mathbf{5 1 . 6} \% \dagger \S \ddagger$ & $48.1 \%$ & $46.5 \%$ & $41.5 \%$ \\
\hline \multirow{7}{*}{$=$} & 倸受 & 566 & $54.0 \% \dagger \ddagger$ & $49.8 \%$ & $55.6 \%$ & $50.5 \%$ \\
\hline & 文内ゼロ & 70 & $0.0 \%$ & $0.0 \%$ & $0.0 \%$ & $0.0 \%$ \\
\hline & 文間ゼロ & 169 & $0.0 \%$ & $0.0 \%$ & $0.0 \%$ & $0.0 \%$ \\
\hline & exo1 & 32 & $0.0 \%$ & $0.0 \%$ & $0.0 \%$ & $0.0 \%$ \\
\hline & exo2 & 4 & $0.0 \%$ & $0.0 \%$ & $0.0 \%$ & $0.0 \%$ \\
\hline & exog & 265 & $0.0 \%$ & $0.0 \%$ & $0.0 \%$ & $0.0 \%$ \\
\hline & 合計 & 1,106 & $32.2 \% \dagger \ddagger$ & $29.3 \%$ & $\mathbf{3 3 . 3} \%$ & $29.8 \%$ \\
\hline
\end{tabular}

表中の記号 †, $\S ， \ddagger は ，(b)$ と，それぞれ (b-1) (b-2) (b-3) との比較で, 有意によかったものを表す．有意 差検定は，ブートストラップ再サンプリング法（1,000 回測定）を使用し，危険率を $5 \%$ とした。なお。 (b) は，表 5 の再掲である. 
本稿の提案方式である表 5 の (a) 適応は, NAIST 訓練では解析できなかったタイプの項も解 析できるようにする効果があった。自動獲得した知識は, すでに解析できる夕イプの項の精度 改善には効果があるが, 対話で新たに出現したタイプの項を解析する効果はない. したがって, たとえ少量でも対話の述語項構造データを作成し，適応させることが望ましい.

\section{4 対話解析例}

図 4 は, 旅行に関する雑談対話の一部について, 正解述語項構造, (a) 適応方式, (b) NAIST 訓練方式, (b-3) NAIST 訓練（ただし, 必須格情報辞書, 係り受け言語モデルなし）の出力を 並べて表示したものである。発話ごとに差異を分析すると, 以下の特徵が得られた.

・ 発話番号 1 で, 正解が $\operatorname{exog}$ になっているのは, アノテータは,「話した」のは発話者 $\mathrm{AB}$ の両方であると判断したためである。本発話の解釈によっては, exo1でも誤りではない と思われる。

・ 発話番号 2 のガ格の正解は exo2である。しかし, (a) 適応は, exo1 を選択した. 日本語 の場合, 一人称・二人称は, 文末表現（この例では「下さい」）に特徵が現れるが, 選択 器にSuffix 素性があるにも関わらず，正しく選択できなかった。

・ 発話番号 3 のガ格の正解は exo1 である. (a) 適応は正しく選択したが, (b)(b-3) NAIST 訓練は, 一人称 /二人称の外界照応をほとんど選択しないため, 発話番号 1 に現れた「私」 を選択した。しかし，発話番号 1 の「私」は発話者 $\mathrm{A}$ を示しており，発話番号 3 の exo1 (発話者 B) とは異なる。もし文間ゼロタイプの項を割り当てるとすると, 発話番号 2 の 「あなた」が正解となる，本稿では，外界照応と人称代名詞を別に扱っているが，本来は 共参照解析を導入して， exo1/exo2 と「私」「あなた」が同一実体であることを認識すべ きである。その際, 発話者がどちらなのか意識して, 同一性を判断する必要がある.

発話番号 6 にも同様な現象が現れているが，ガ格正解 exo2 に相当する表現が発話番号 2 「あなた」まで遡らなければならないため, (b)(b-3) NAIST 訓練では, exog となった.

- 発話番号 3 の二格の正解は「海外旅行」だが, (b-3) NAIST 訓練（自動獲得知識なし）で は，NULL と誤った。「海外旅行にはまる」は，NAIST コーパス訓練セットには出現せ ず，係り受け言語モデルの三つ組に出現する表現だったため，係り受け言語モデルなし の NAIST 訓練では解析に失敗した。

・ 発話番号 5 の二格の正解は,「スペインとポルトガル」であるベきだが, 本稿の方式は文 節を単位に処理するため，2 文節以上にまたがる名詞句は，主辞だけを付与する仕様で ある。

また, 発話番号 4 のガ格の正解は, 直前発話（発話番号 3 ）全体と考えることもできる. しかし, 文節単位に格要素を割り当てるため, アノテータはもっとも近い表現「海外旅 行」を正解として割り当てた. 


\begin{tabular}{|c|c|c|c|c|c|c|}
\hline \multirow[t]{3}{*}{$\begin{array}{c}\text { 番号 } \\
1\end{array}$} & \multirow[t]{3}{*}{$\begin{array}{c}\text { 発話者 } \\
\mathrm{A}\end{array}$} & \multicolumn{5}{|c|}{$\begin{array}{l}\text { 発話 } \\
\text { 先程は私の 趣味について 話しましたカ }\end{array}$} \\
\hline & & 述語 & 正解述語項構造 & (a) 適応 & (b) NAIST 訓練 & $\begin{array}{l}\text { (b-3) NAIST 訓練 } \\
\text { 自動獲得知識なし }\end{array}$ \\
\hline & & 話す & $\begin{array}{l}\text { ガ: exog } \\
\text { ヨ: 趣味 } \\
\text { 二: NULL }\end{array}$ & $\begin{array}{l}\text { ガ: exo1* } \\
\text { ヨ: NULL* } \\
\text { ニ: NULL }\end{array}$ & $\begin{array}{l}\text { ガ: 先程* } \\
\text { ヨ: NULL* } \\
\text { ニ: NULL }\end{array}$ & $\begin{array}{l}\text { ガ: 先程* } \\
\text { ヨ: NULL* } \\
\text { ニ: NULL }\end{array}$ \\
\hline
\end{tabular}

2 A あなたの趣味を 教えて下さい。

\begin{tabular}{c|l|l|l|l}
\hline 述語 & 正解述語項構造 & (a) 適応 & (b) NAIST 訓練 & $\begin{array}{l}\text { (b-3) NAIST 訓練 } \\
\text { 自動獲得知識なし }\end{array}$ \\
\hline \multirow{3}{*}{ 教える } & ガ: exo2 & ガ: exo1* & ガ: 私* & ガ: 私* \\
& ニ: exo1 & $\begin{array}{l}\text { キ: 趣味 } \\
\text { ニ: NULL* }\end{array}$ & $\begin{array}{l}\text { ヨ: 趣味 } \\
\text { ニ: NULL* }\end{array}$ & $\begin{array}{l}\text { キ: 趣味 } \\
\text { ニ: NULL* }\end{array}$ \\
\hline
\end{tabular}

3 B 母の 影響で、最近は 海外旅行にはまってます。

\begin{tabular}{|c|c|c|c|c|}
\hline 述語 & 正解述語項構造 & (a) 適応 & (b) NAIST 訓練 & $\begin{array}{l}\text { (b-3) NAIST 訓練 } \\
\text { 自動獲得知識なし }\end{array}$ \\
\hline はまる & $\begin{array}{l}\text { ガ: exo1 } \\
\text { ヨ: NULL } \\
\text { 二: 海外旅行 }\end{array}$ & $\begin{array}{l}\text { ガ: exo1 } \\
\text { ヨ: NULL } \\
\text { 二: 海外旅行 }\end{array}$ & $\begin{array}{l}\text { ガ: 私* } \\
\text { ヨ: NULL } \\
\text { 二: 海外旅行 }\end{array}$ & $\begin{array}{l}\text { ガ: 私* } \\
\text { 尹: NULL } \\
\text { 二: NULL* }\end{array}$ \\
\hline
\end{tabular}

A

\begin{tabular}{l|l|l|l|l} 
すごいですね。 \\
\hline 述語 & 正解述語項構造 & (a) 適応 & (b) NAIST 訓練 & $\begin{array}{l}\text { (b-3) NAIST 訓練 } \\
\text { 自動獲得知識なし }\end{array}$ \\
\hline \multirow{3}{*}{ すごい } & ガ: 海外旅行 & ガ: exog* & ガ: 私* & ガ: 私* \\
& ヨ: NULL & ヨ: NULL & タ: NULL & ヨ: NULL \\
& ニ: NULL & ニ: NULL & ニ: NULL & ニ: NULL \\
\hline
\end{tabular}

5 B この間、スペインとポルトガルに行ってきました。

\begin{tabular}{|c|c|c|c|c|}
\hline 述語 & 正解述語項構造 & (a) 適応 & (b) NAIST 訓練 & $\begin{array}{l}\text { (b-3) NAIST 訓練 } \\
\text { 自動獲得知識なし }\end{array}$ \\
\hline 行く & $\begin{array}{l}\text { ガ: exo1 } \\
\text { ᄏ: NULL } \\
\text { ニ: ポルトガル }\end{array}$ & $\begin{array}{l}\text { ガ: exo1 } \\
\text { 尹: NULL } \\
\text { ニ: ポルトガル }\end{array}$ & $\begin{array}{l}\text { ガ: 私* } \\
\text { ヨ: NULL } \\
\text { ニ: ポルトガル }\end{array}$ & $\begin{array}{l}\text { ガ: 私* } \\
\text { ヨ: NULL* } \\
\text { ニ: ポルトガル }\end{array}$ \\
\hline
\end{tabular}

6

A

何日間 行かれたのですか？

\begin{tabular}{|c|c|c|c|c|}
\hline 述語 & 正解述語項構造 & (a) 適応 & (b) NAIST 訓練 & $\begin{array}{l}\text { (b-3) NAIST 訓練 } \\
\text { 自動獲得知識なし }\end{array}$ \\
\hline $0<$ & $\begin{array}{l}\text { ガ: exo2 } \\
\text { ᄏ: NULL } \\
\text { ニ: ポルトガル }\end{array}$ & $\begin{array}{l}\text { ガ: exo2 } \\
\text { 尹: NULL } \\
\text { ニ: ポルトガル }\end{array}$ & $\begin{array}{l}\text { ガ: exog* } \\
\text { 尹: NULL } \\
\text { ニ: NULL* }\end{array}$ & $\begin{array}{l}\text { ガ: exog* } \\
\text { ヨ: 何日間* } \\
\text { 二: NULL* }\end{array}$ \\
\hline
\end{tabular}

7 B 8 日間ですよ。

\begin{tabular}{c|l|l|l|l}
\hline 述語 & 正解述語項構造 & (a) 適応 & (b) NAIST 訓練 & $\begin{array}{l}\text { (b-3) NAIST 訓練 } \\
\text { 自動獲得知識なし }\end{array}$ \\
\hline \multirow{3}{*}{8 日間 } & ガ: exog & ガ: exog & ガ: exog & ガ: 私* \\
& キULL & ヨ: NULL & タ: NULL & タ: NULL \\
& ニ NUL & ニ: NULL & ニ: NULL & ニ: NULL \\
\hline
\end{tabular}

図 4 対話例と, 正解述語項構造および述語項構造解析結果（*は解析誤りを表す） 
・ 発話番号 6 において, (a) 適応は, 二格「ポルトガル」を前文から正しく補完した。なお, 「ポルトガルに行く」は, NAIST コーパス訓練セットには存在しないが，係り受け言語 モデルの三つ組には存在する表現である.

\section{7 まとめ}

本稿では，対話解析のための述語項構造解析を提案した。われわれはこれを新聞から対話へ の一種のドメイン適応とみなし, 従来新聞記事で研究されていた述語項構造解析を, 対話に適用 した．対話と新聞記事では項の分布が異なるため，素性空間拡張法を用いて，モデルパラメー 夕を適応させた。また訓練コーパスに現れない未知語を補完するため, 大規模平文データから, 必須格情報, 係り受け言語モデルを自動獲得し, 項選択器のモデルに適用した。

結果，少量でも対話コーパスを訓練に加えることで，新聞記事のコーパスだけでは解析でき なかったタイプ（ガ格の一人称・二人称ゼロ代名詞や, 文間ゼロ代名詞, 外界照応）も解析可能 となった。 ただし，パラメー夕適応自体の効果は限定的であった。また，自動獲得知識の有効 性は，訓練セットがテストセットをどの程度カバーしているかに依存する。必須格情報は，テ ストセットに出現する述語の大部分が訓練セットに出現していたため, 必須格情報のカバレッ ジの影響はほとんどなかった。一方係り受け言語モデルでは, テストセットに出現する述語, 格, 名詞句の三つ組の $21 \%$ しか訓練セットでカバーしていなかったため, カバレッジの高いモ デルの精度が向上した。特に，ヲ格二格に関しては，三つ組カバレッジが高い方が，ゼロ代名 詞照応解析精度の向上に寄与することを確認した。

なお，必須格情報および係り受け言語モデルは，格フレームの選択選好とみなすこともでき る. 格フレームは, 大規模コーパスから自動獲得したものが存在するので (河原, 黒橋 2005), これを利用する方法もある。両者の比較は, 今後検討してゆきたい.

今回は, パラメータ分布の差異, 語彙のカバレッジに着目したが, 新聞と対話では, 他にも さまざまな違いがあると考えられる。たとえば，話者交替は対話特有の現象であるが，それが 述語項構造やゼロ代名詞にどう影響するかなどは，本稿では扱わなかった。また，われわれは 文脈管理に，対話システムの発話管理機能を利用することを考えているが，対話システムとし ての有効性評価も実施する予定である.

\section{謝 辞}

本論文の一部は, the 25th International Conference on Computational Linguistics (COLING 2014)で発表したものである (Imamura, Higashinaka, and Izumi 2014). 


\section{参考文献}

Carreras, X. and Màrquez, L. (2004). "Introduction to the CoNLL-2004 Shared Task: Semantic Role Labeling." In HLT-NAACL 2004 Workshop: 8th Conference on Computational Natural Language Learning (CoNLL-2004), pp. 89-97, Boston, Massachusetts, USA.

Carreras, X. and Màrquez, L. (2005). "Introduction to the CoNLL-2005 Shared Task: Semantic Role Labeling." In Proceedings of the 9th Conference on Computational Natural Language Learning (CoNLL-2005), pp. 152-164, Ann Arbor, Michigan, USA.

Coppola, B., Moschitti, A., and Riccardi, G. (2009). "Shallow Semantic Parsing for Spoken Language Understanding." In Proceedings of Human Language Technologies: The 2009 Annual Conference of the North American Chapter of the Association for Computational Linguistics, Companion Volume: Short Papers, pp. 85-88, Boulder, Colorado, USA.

Daumé, III, H. (2007). "Frustratingly Easy Domain Adaptation." In Proceedings of the 45th Annual Meeting of the Association of Computational Linguistics, pp. 256-263, Prague, Czech Republic.

Gerber, M. and Chai, J. Y. (2012). "Semantic Role Labeling of Implicit Arguments for Nominal Predicates." Computational Linguistics, 38 (4), pp. 755-798.

Gildea, D. and Jurafsky, D. (2002). "Automatic Labeling of Semantic Roles." Computational Linguistics, 28 (3), pp. 245-288.

萩行正嗣, 河原大輔, 黑橋禎夫 (2014). 外界照応および著者・読者表現を考慮した日本語ゼロ 照応解析. 自然言語処理, 21 (3), pp. 563-600.

林部祐太, 小町守, 松本裕治 (2014). 述語と項の位置関係ごとの候補比較による日本語述語項 構造解析. 自然言語処理, 21 (1), pp. 3-25.

Hovy, E., Marcus, M., Palmer, M., Ramshaw, L., and Weischedel, R. (2006). "OntoNotes: The 90\% Solution." In Proceedings of the Human Language Technology Conference of the NAACL, Companion Volume: Short Papers, pp. 57-60, New York, USA.

飯田龍, 小町守, 井之上直也, 乾健太郎, 松本裕治 (2010). 述語項構造と照応関係のアノテー ション：NAIST テキストコーパス構築の経験から. 自然言語処理, 17 (2), pp. 25-50.

Iida, R., Komachi, M., Inui, K., and Matsumoto, Y. (2007). "Annotating a Japanese Text Corpus with Predicate-Argument and Coreference Relations." In Proceedings of the Linguistic Annotation Workshop, pp. 132-139, Prague, Czech Republic.

Imamura, K., Higashinaka, R., and Izumi, T. (2014). "Predicate-Argument Structure Analysis with Zero-Anaphora Resolution for Dialogue Systems." In Proceedings of COLING 2014, the 25th International Conference on Computational Linguistics: Technical Papers, pp. 806-815, 
Dublin, Ireland.

Imamura, K., Saito, K., and Izumi, T. (2009). "Discriminative Approach to Predicate-Argument Structure Analysis with Zero-Anaphora Resolution." In Proceedings of the ACL-IJCNLP 2009 Conference Short Papers, pp. 85-88, Singapore.

Jiang, Z. P. and Ng, H. T. (2006). "Semantic Role Labeling of NomBank: A Maximum Entropy Approach." In Proceedings of the 2006 Conference on Empirical Methods in Natural Language Processing, pp. 138-145, Sydney, Australia.

河原大輔, 黒橋禎夫 (2005). 格フレーム辞書の漸次的自動構築. 自然言語処理, 12 (2), pp. 109-131. Komachi, M., Iida, R., Inui, K., and Matsumoto, Y. (2007). "Learning-Based Argument Structure Analysis of Event-Nouns in Japanese." In Proceedings of the Conference of the Pacific Association for Computational Linguistics (PACLING), pp. 208-215, Melbourne, Australia. Kudo, T. and Matsumoto, Y. (2002). "Japanese Dependency Analysis using Cascaded Chunking." In CoNLL 2002: Proceedings of the 6th Conference on Natural Language Learning 2002 (COLING 2002 Post-Conference Workshops), pp. 63-69, Taipei, Taiwan.

Kudo, T., Yamamoto, K., and Matsumoto, Y. (2004). "Applying Conditional Random Fields to Japanese Morphological Analysis." In Proceedings of EMNLP 2004, pp. 230-237, Barcelona, Spain.

Laparra, E. and Rigau, G. (2013). "ImpAr: A Deterministic Algorithm for Implicit Semantic Role Labelling." In Proceedings of the 51st Annual Meeting of the Association for Computational Linguistics (Volume 1: Long Papers), pp. 1180-1189, Sofia, Bulgaria.

Màrquez, L., Carreras, X., Litkowski, K. C., and Stevenson, S. (2008). "Semantic Role Labeling: An Introduction to the Special Issue." Computational Linguistics, 34 (2), pp. 145-159. 松林優一郎, 飯田龍, 笹野遼平, 横野光, 松吉俊, 藤田篤, 宮尾祐介, 乾健太郎 (2014). 日本語 文章に対する述語項構造アノテーション仕様の考察. 自然言語処理, 21 (2), pp. 333-377.

Palmer, M., Gildia, D., and Kingsbury, P. (2005). "The Proposition Bank: An Annotated Corpus of Semantic Roles." Computational Linguistics, 31 (1), pp. 71-105.

Pradhan, S., Moschitti, A., and Xue, N. (Eds.) (2012). Joint Conference on EMNLP and CoNLL: Proceeding of the Shared Task: Modeling Multilingual Unrestricted Coreference in Onto Notes, Jeju, Korea.

Pradhan, S. S., Ward, W., and Martin, J. H. (2008). "Towards Robust Semantic Role Labeling." Computational Linguistics, 34 (2), pp. 289-310.

Ruppenhofer, J., Ellsworth, M., Petruck, M. R., Johnson, C. R., and Scheffczyk, J. (2006). FrameNet II: Extended Theory and Practice. International Computer Science Institute, Berkeley, California. Distributed with the FrameNet data. 
Sasano, R., Kawahara, D., and Kurohashi, S. (2008). "A Fully-Lexicalized Probabilistic Model for Japanese Zero Anaphora Resolution." In Proceedings of the 22nd International Conference on Computational Linguistics (COLING 2008), pp. 769-776, Manchester, UK.

Sasano, R., Kawahara, D., Kurohashi, S., and Okumura, M. (2013). "Automatic Knowledge Acquisition for Case Alternation between the Passive and Active Voices in Japanese." In Proceedings of the 2013 Conference on Empirical Methods in Natural Language Processing, pp. 1213-1223, Seattle, Washington, USA.

Stolcke, A., Zheng, J., Wang, W., and Abrash, V. (2011). "SRILM at Sixteen: Update and Outlook." In Proceedings of IEEE Automatic Speech Recognition and Understanding Workshop (ASRU 2011), Waikoloa, Hawaii, USA.

Taira, H., Fujita, S., and Nagata, M. (2008). "A Japanese Predicate Argument Structure Analysis using Decision Lists." In Proceedings of the 2008 Conference on Empirical Methods in Natural Language Processing, pp. 523-532, Honolulu, Hawaii, USA.

平博順, 田中貴秋, 藤田早苗, 永田昌明 (2014). ビジネスメールに対する日本語述語項構造解 析の検討. 言語処理学会第 20 回年次大会発表論文集, pp. 1019-1022, 札幌.

Tur, G., Hakkani-Tür, D., and Chotimongkol, A. (2005). "Semi-Supervised Learning for Spoken Language Understanding Using Semantic Role Labeling." In Proceedings of Automatic Speech Recognition and Understanding Workshop (ASRU 2005), pp. 232-237, San Juan, Puerto Rico.

吉川克正, 浅原正幸, 松本裕治 (2013). Markov Logic による日本語述語項構造解析. 自然言語 処理, 20 (2), pp. 251-271.

\section{略歴}

今村＼cjkstart賢治：1985 年千葉大学工学部電気工学科卒業. 同年～ 2014 年日本電信電 話株式会社. 1995 年〜1998 年 NTTソフトウェア株式会社. 2000 年〜2006 年 ATR 音声言語コミュニケーション研究所. 2014 年より株式会社 ATR-Trek 所 属として, 独立行政法人情報通信研究機構 (NICT) へ出向. 現在 NICT 先進 的音声翻訳研究開発推進センター専門研究員. 主として自然言語処理技術の 研究・開発に従事. 博士 (工学), 電子情報通信学会, 情報処理学会, 言語処 理学会, ACL 各会員.

東中竜一郎：1999 年に慶應義塾大学環境情報学部卒業, 2001 年に同大学大学院 政策・メディア研究科修士課程，2008 年に博士課程修了。博士 (学術)。2 2001 年に日本電信電話株式会社入社. 現在, NTTメディアインテリジェンス研究 所にて勤務。音声言語メディアプロジェクトにて, 質問応答システム・音声 
対話システムの研究に従事. 言語処理学会, 人工知能学会, 情報処理学会, 電 子情報通信学会, 各会員. 2004 年から 2006 年にかけて, 英国シェフィール ド大学客員研究員.

泉 朋子： 2005 年北海道教育大学国際理解教育課程卒業, 2007 年ボストン大 学大学院人文科学部応用言語学科修了, 2008 年日本電信電話株式会社入社. 2014 年京都大学大学院情報学研究科博士後期課程修了. 博士 (情報学). 現 在, NTTメディアインテリジェンス研究所研究員, 自然言語処理研究開発に 従事. 言語処理学会会員.

(2014 年 6 月 26 日 受付)

(2014 年 9 月 30 日 再受付)

(2014 年 11 月 7 日 採録) 